\title{
Pengembangan Media Pembelajaran
} Menggunakan Program Resitasi Untuk Meningkatkan Kemampuan Siswa Dalam Mengerjakan Soal Ujian Nasional di SMA

\author{
Salsabila Indana Zulfa*, Gitik Safitri F, Desy Aditya Lutfa Isnaini and Vani Rahmasari \\ Received: 10 Des., 2019 | Accepted: 17 Jan., 2020 | Published: 16 June, 2020 | DOI: 10.22146/jfi.v24i1.52405
}

\begin{abstract}
Ringkasan
Penelitian ini bertujuan untuk mempermudah peserta didik dalam memahami soal-soal pada Ujian Nasional (UN) materi fisika SMA melalui program yang telah dirancang yaitu Simak UN Fisika SMA. Program yang telah dikembangkan ini merupakan program yang layak digunakan dalam membantu peserta didik untuk mengerjakan soal-soal UN. Penelitian ini menggunakan model pengembangan 4D. Tahapan yang dilewati dalam penelitian ini, yaitu: Define (pendefinisian), Design (perancangan), dan Develop (pengembangan). Dalam penelitian tidak melewati tahapan terakhir yaitu Disseminate (penyebarluasan) dikarenakan keterbatasan waktu dalam penelitian. Validasi dilakukan oleh dua orang ahli yakni: ahli media dan ahli materi. Hasil penelitian ini menunjukkan bahwa program resitasi ini mendapat persentase penilaian dari segi media dengan kategori aspek tampilan sebesar $86 \%$, aspek tulisan $84 \%$, dan aspek rekayasa perangkat lunak sebesar $80 \%$ dengan kesimpulan bahwa program resitasi ini layak untuk diaplikasikan oleh peserta didik dengan persentase $83,33 \%$. Sedangkan pada persentase penilaian materi total keseluruhan sebesar $84,33 \%$ dengan rincian sebagai berikut $88 \%$ untuk aspek materi, $89 \%$ aspek pembelajaran, dan $76 \%$ aspek evaluasi. Berdasarkan hal tersebut program resitasi ini dapat digunakan sebagai salah satu media pembelajaran untuk membantu peserta didik dalam mempersiapkan UN.
\end{abstract}

Kata Kunci : program resitasi, materi fisika, 4D.

Abstract

This study aims to facilitate students in understanding the questions on the National Examination (UN) high school physics material through a program that has been designed, namely High School Physics UN Exam. The program that has been developed is a program that is suitable to be used in helping students to work on UN questions. This study uses a 4D development model. The stages that were passed in this study, namely: Define, Design, and Develop. In the study did not pass the last stage, namely Disseminate (dissemination) due to time constraints in the study. Validation was carried out by two experts namely: expert media and material experts The results of this study indicate that the recitation program received a percentage of ratings in terms of media with a display aspect category of $86 \%$, a writing aspect of $84 \%$, and a software engineering aspect of $80 \%$ with the conclusion that the recitation program was feasible to be applied by students with a percentage of $83,33 \%$, while the percentage of assessment of the total material total of $84,33 \%$ with the following details $88 \%$ for the material aspects, $89 \%$ learning aspects, and $76 \%$ evaluation aspects. Based on this recitation program can be used as one of the learning media to help students prepare for the national examination.

Keywords: recitation program; physics material; 4D.

\footnotetext{
${ }^{*}$ Correspondence: salsabilazulfa.1703216@students.um.ac.id Program Studi S1 Pendidikan Fisika, Fakultas Matematikan dan IImu Pengetahuan Alam, Universitas Negeri Malang, Kota Malang, Indonesia Full list of author information is available at the end of the article ${ }^{\dagger}$ Equal contributor
}

\section{PENDAHULUAN}

Pendidikan merupakan suatu hal wajib yang harus didapatkan oleh setiap orang. Dalam pelaksanaannya pendidikan dibagi berjenjang dari yang paling dasar 
hingga tinggi. Untuk mengetahui apakah siswa telah mampu menuju jenjang pendidikan yang lebih tinggi perlu adanya evaluasi guna mengukur kemampuan siswa. Salah satu bentuk evaluasi tersebut adalah ujian nasional yang dijadikan sebagai salah satu syarat untuk kelulusan pada suatu jenjang pendidikan. Menurut Puspendik ujian nasional atau UN digunakan untuk mengukur kompetensi lulusan yang telah dicapai siswa sebagai hasil yang diperoleh dari proses pembelajaran pada jenjang satuan pendidikan dasar dan menengah [1].

Fisika merupakan satu dari tiga mata pelajaran pilihan yang diujikan pada UN untuk program IPA SMA. Berdasarkan data Puspendik menunjukkan bahwa capaian hasil UN fisika siswa pada tahun 2018/2019 berada pada urutan terbawah dengan nilai rata-rata $46,47 \%$ dibandingkan mata pelajaran pilihan pada program MIPA lainnya biologi 50,61\% dan kimia 50,99\%. Siswa tidak mampu mengerjakan soal UN fisika dikarenakan masih kesulitan untuk memahami permasalahan yang disajikan [1]. Selain itu kesulitan siswa dalam mengerjakan soal fisika juga dapat diakibatkan oleh metode pembelajaran sebelumnya, media, minat belajar, situasi dan kondisi siswa $[2]$.

Berdasarkan paparan tersebut perlu adanya media pembelajaran yang dapat membantu siswa untuk berlatih dalam mengerjakan soal UN. Penelitian yang dilakukan oleh Yuniati, dkk memperoleh hasil bahwa game puzzle berbasis Fuzzy C-Mean dapat mempermudah pemetaan soal UN fisika serta menyediakan latihan soal yang menyenangkan dan menantang sehingga siswa dapat termotivasi untuk berlatih [3]. Hal ini menunjukkan bahwa media pembelajaran yang menyenangkan dapat meningkatkan motivasi siswa untuk berlatih mengerjakan soal UN. Namun, dalam latihan soal yang diberikan haruslah mampu meningkatkan pemahaman siswa mengenai masalah yang diberikan.

Program resitasi berbantuan komputer merupakan program yang berisi latihan soal dengan format pilihan ganda disertai balikan pada tiap pilihannya baik pilihan benar maupun salah dengan tujuan memberikan bantuan dan penguatan terhadap kemampuan penyelesaian soal [4, 5, 6, 7]. Program resitasi sebelumnya dibuat dengan Wondershare Quiz Creator versi 4.5.1. Untuk lebih mempermudah pembuatannya peneliti mengembangkan program ini dengan membuat latihan soal menggunakan Microsoft Power Point (PPT). Kelebihan Ms. Power Point dibandingkan aplikasi lainnya relatif mudah dalam penggunaannya dan sangat dikenal oleh pengguna Ms. Word karena penggunaan ikonnya hampir sama, serta dalam penggunaanya hanya dibutuhkan inovasi dan daya kreativitas dari guru [8].
Tabel 1: Interval nilai hasil validasi ahli media [9]

\begin{tabular}{cll}
\hline No & Interval Nilai (\%) & Kategori \\
\hline 1 & $76-100$ & Sangat Baik \\
2 & $51-75$ & Baik \\
3 & $26-50$ & Cukup Baik \\
4 & $0-25$ & Kurang Baik \\
\hline
\end{tabular}

\section{METODE PENELITIAN}

Penelitian ini menggunakan metode penelitian dan pengembangan atau Research and Development $(R$ and $D)$. Model penelitian yang digunakan adalah model pengembangan $4 D$ (four D-models). Tahapan model 4D ini dibagi menjadi 4, yakni: (1) Define (tahap pendefinisan); (2) Design (tahap perencanaan); (3) Development (tahap pengembangan); (4) Disseminate (tahap penyebaran). Masing-masing tahapan dalam penelitian ini memiliki sub tahapan yang lain. Akan tetapi, dalam penelitian ini tidak digunakan tahap penyebaran (Disseminate) dikarenakan adanya keterbatasan waktu untuk melakukan penelitian pengembangan ini.

Tahap yang pertama adalah tahap Define (tahap pendefinisian) yang berfungsi untuk menetapkan dan mendefinisikan syarat-syarat pembelajaran, antara lain terbagi menjadi 5 tahapan, yakni analisis ujung depan, analisis pembelajar, analisis tugas, analisis konsep dan perumusan tujuan-tujuan instruksional. Tahap Design (tahap perencanaan) merupakan tahap kedua yang memiliki fungsi untuk merancang perangkat pembelajaran, yang terdiri dari penyusunan standar tes, pemilihan media, pemilihan format dan penyusunan rancangan awal. Tahapan yang ketiga adalah tahap Development (tahap pengembangan), yang berfungsi untuk menghasilkan produk akhir dari perangkat pembelajaran setelah melewati revisi yang sebelumnya telah dinilai dan diberikan masukan dari para ahli dan data hasil uji coba.

Teknik pengumpulan data berupa angket validasi oleh ahli media dan dikategorikan dalam 4 jenis, yaitu nilai (4) kategori sangat baik, nilai (3) kategori baik, nilai (2) cukup baik dan nilai (1) yang berarti kurang baik. 4 jenis kategori tersebut dipersentasekan pada Tabel 1.

Skema hubungan antar tahap dan antar fase seperti pada Gambar 1.

\section{HASIL DAN PEMBAHASAN}

Produk yang dikembangkan oleh peneliti ini adalah berupa program resitasi terkait materi-materi fisika persiapan Ujian Nasional (UN) SMA. Produk yang akan diuji coba publik ini merupakan produk dengan pengembangan menggunakan aplikasi power point dengan uji coba pengoperasian program 


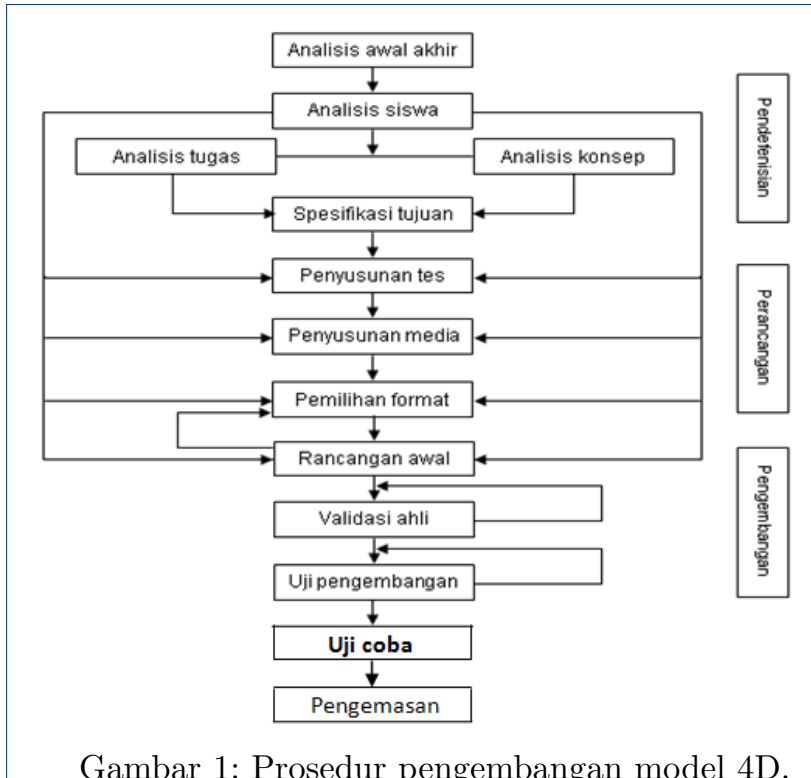

Gambar 1: Prosedur pengembangan model 4D.

resitasi dan berupa angket untuk mengetahui respon publik terhadap pengembangan program resitasi ini menggunakan google form.

Gambar di bawah ini menunjukkan tampilan awal dari program resitasi UN yang terdiri dari tiga pilihan menu, yaitu: petunjuk penggunaan program, materi seputar fisika SMA, dan soal-soal UN fisika SMA. Gambar 2 menunjukkan tampilan salah satu dari tiga menu utama yang tersedia, yaitu mengenai materi fisika.

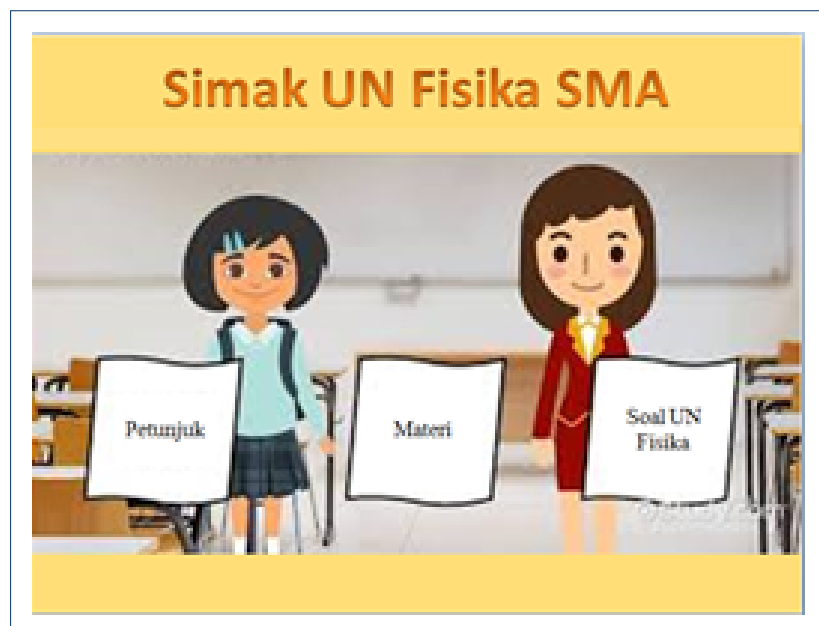

Gambar 2: Tampilan menu utama dari program resitasi.

Sedangkan Gambar 3 menampilkan mengenai cover untuk menu materi fisika. Gambar 4 menampilkan mengenai soal fisika pada program resitasi dengan contoh pada materi fluida. Di setiap slide tampilan terdapat tombol exit dan menu untuk kembali ke tampilan menu utama.
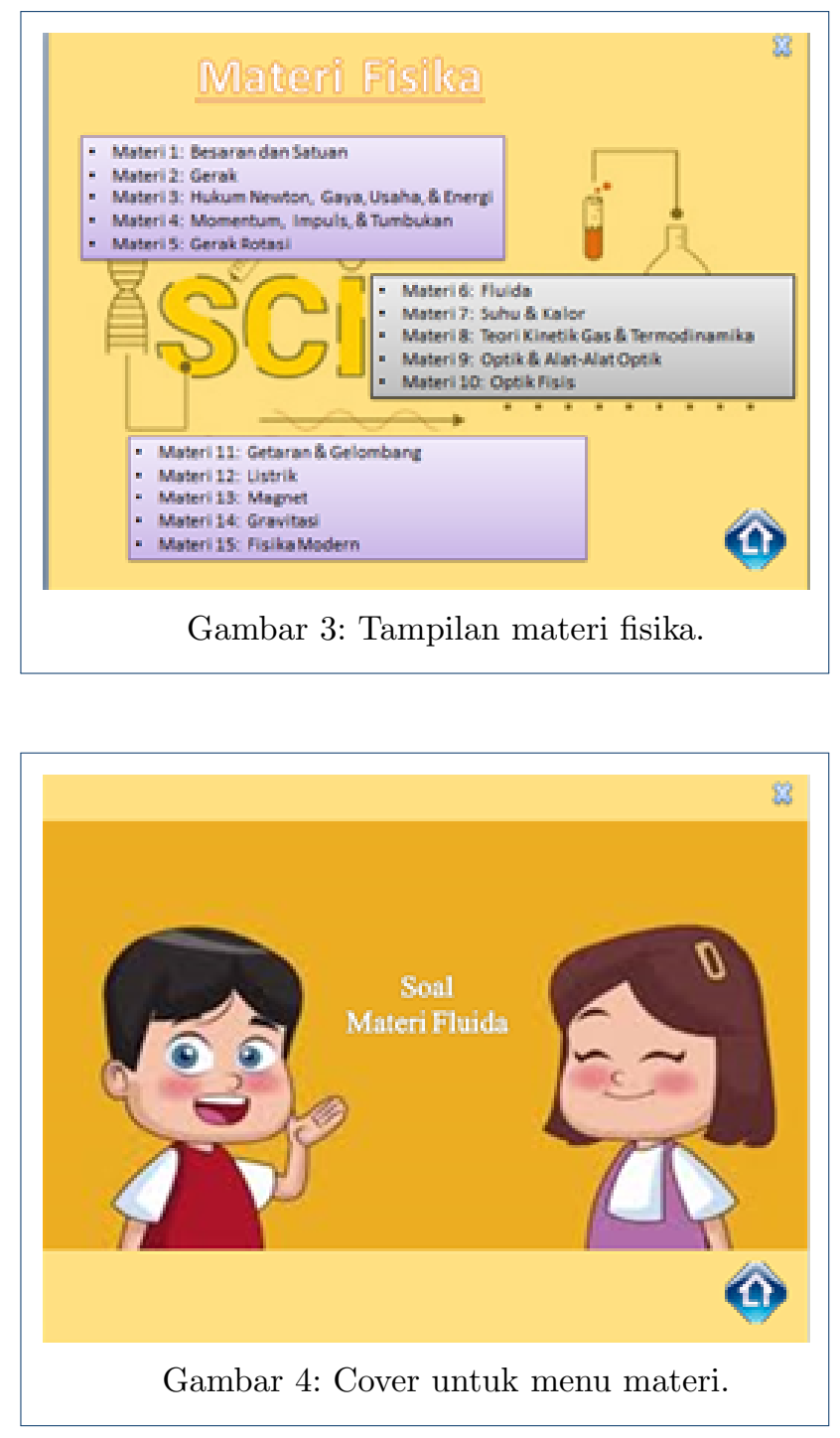

Produk yang telah kami rancang ini telah divalidasi oleh ahli media dan ahli materi. Uji validasi media dilakukan oleh Monica Widyaswari, M.Pd. salah satu dosen FIP UM yang memiliki pengalaman di bidang pengembangan media. Sedangkan untuk uji materi diuji oleh salah satu pendidik SMA yaitu Mukhlas, S.Pd.

Pada uji validasi media diperoleh rentang nilai 80\%-86\% dengan uraian sebagai berikut, aspek tampilan pada program ini mendapat nilai dengan persentase $86 \%$, sedangkan untuk aspek tulisan mendapat penilaian sebesar $84 \%$, dan untuk aspek penilaian rekayasa perangkat lunak mendapat penilaian $80 \%$. Rentang perolehan persentase penilaian tersebut berada di kategori sangat baik dan 


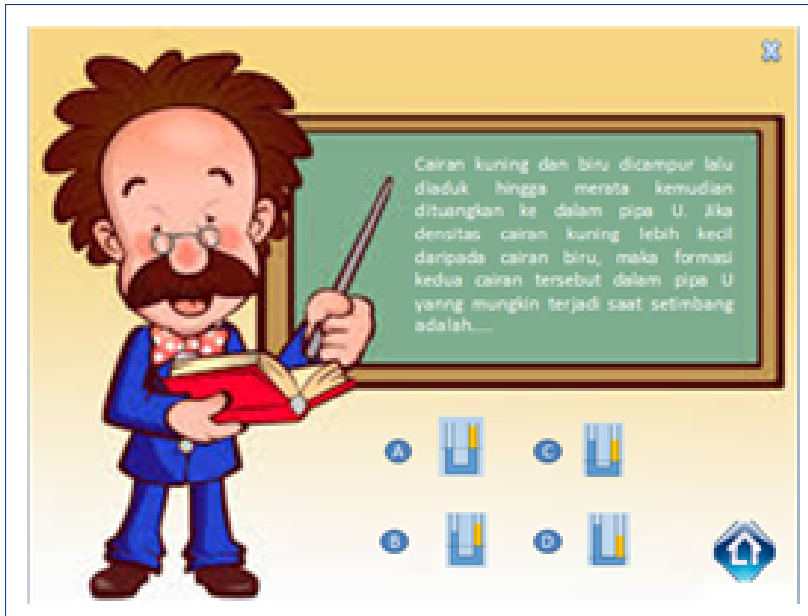

Gambar 5: Soal pada program resitasi.

baik, di mana pada aspek tampilan mendapat kategori sangat baik dan di kategori tulisan serta rekayasa perangkat lunak berada di kategori baik. Secara keseluruhan program ini dianjurkan untuk digunakan guna membantu peserta didik dalam mempersiapkan UN $83,33 \%$.

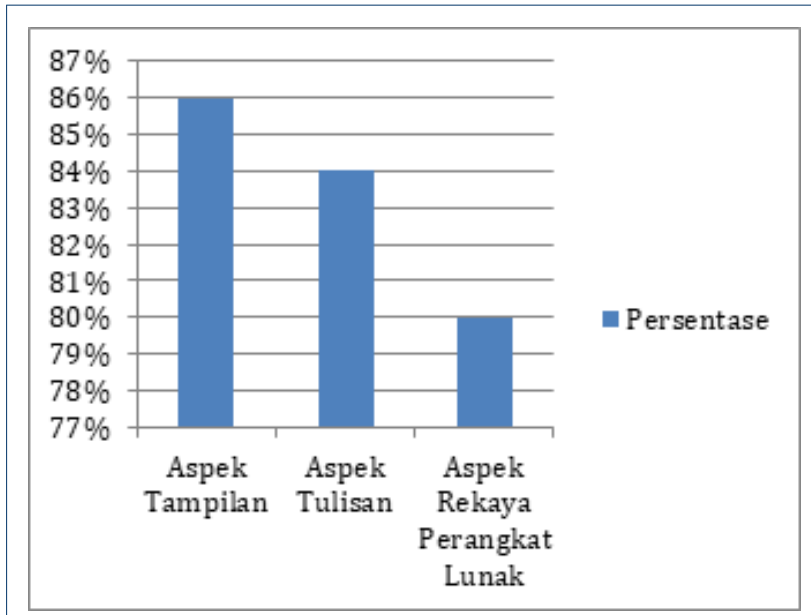

Gambar 6: Grafik penilaian ahli media.

Kualitas program resitasi apabila ditinjau dari aspek materi, aspek pembelajaran, aspek evaluasi. Pada aspek materi mendapat persentase penilaian sebesar 88\%, sedangkan pada aspek pembelajaran mendapat persentase penilaian 89\%, dan untuk persentase penilaian aspek evaluasi mendapat $76 \%$ dengan kategori baik. Sedangkan pada aspek materi dan pembelajaran mendapat kategori sangat baik. Berdasarkan perolehan persentase penilaian dapat dinyatakan bahwa materi yang ada pada program tersebut dapat dianjurkan untuk digunakan sebagai media pembelajaran dengan total secara keseluruhan adalah $84,33 \%$.

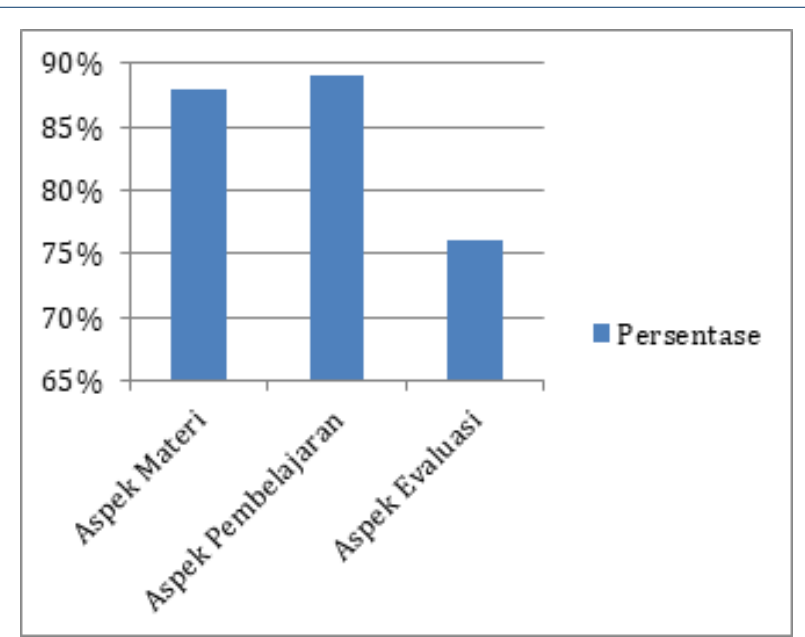

Gambar 7: Grafik penilaian ahli materi.

Hasil revisi dari program resitasi ini adalah adanya tampilan skor yang awalnya tidak direncanakan pemberian skor, namun setelah mendapat masukan dari ahli media dan materi program ini dilengkapi dengan skor keberhasilan peserta didik menjawab soal-soal yang ada.

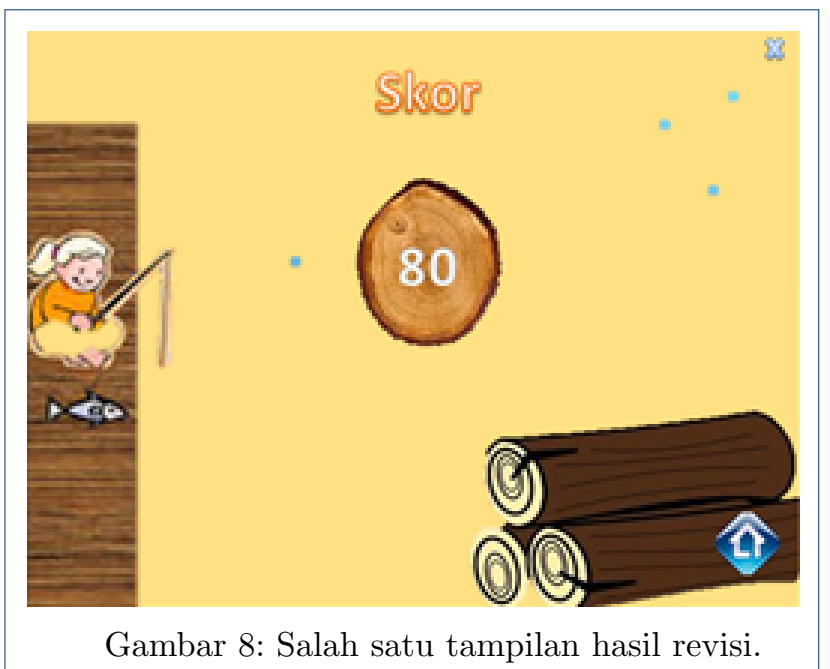

\section{KESIMPULAN}

Media yang dikembangkan pada penelitian ini adalah program resitasi berupa latihan soal menggunakan powerpoint. Media yang dihasilkan atau yang telah dikembangkan memiliki nilai validitas dan nilai efektifitas yang tinggi di mana pemahaman yang dialami oleh siswa menjadi bertambah karena 
ketika soal diberikan dan siswa menjawab salah terdapat penjelasan mengapa jawaban tersebut salah dan diberitahukan jawaban yang benar disertai penjelasannya juga. Dengan perolehan persentase penilaian validasi media sebesar $83,33 \%$ sedangkan untuk validasi materi sebesar $84,33 \%$.

\section{PENULIS}

1 Salsabila Indana Zulfa

Dari :

(1) Program Studi S1 Pendidikan Fisika, Fakultas Matematikan dan Ilmu Pengetahuan Alam, Universitas Negeri Malang

\section{Gitik Safitri F}

Dari :

(1) Program Studi S1 Pendidikan Fisika, Fakultas Matematikan dan Ilmu Pengetahuan Alam, Universitas Negeri Malang

3 Desy Aditya Lutfa Isnaini

Dari :

(1) Program Studi S1 Pendidikan Fisika, Fakultas Matematikan dan Ilmu Pengetahuan Alam, Universitas Negeri Malang

4 Vani Rahmasari

Dari :
(1) Program Studi S1 Pendidikan Fisika, Fakultas Matematikan dan Ilmu Pengetahuan Alam, Universitas Negeri Malang

Pustaka

1. Laporan Hasil Ujian Nasional; 2019. Available from: https://hasilun. puspendik.kemdikbud.go.id/\{\#\}2019!smp! capaian\{_\}nasional! $99\{\&\} 99\{\&\} 999$ ! $T\{\&\} T\{\&\} T\{\&\} T\{\&\} 1\{\&\} T ! 1 !\{\&\}$

2. Sari D, Sudarti S, Bektiarso S. Analisis Kesalahan Siswa Mengerjakan Soal UN Materi Rangkaian Arus Listrik Searah Menggunakan Metode Polya. FKIP e-PROCEEDING. 2019;3(2):235-240.

3. Yuniati L, Syukur A, Wahono RS. Game Puzzle Berbasis Fuzzy C-Mean untuk Memetakan Soal Ujian Nasional Fisika SMA. Jurnal Teknodik. 2018;14(1):44-54.

4. Sutopo S, Jayanti IBR, Wartono W. Efektivitas Program Resitasi Berbasis Komputer untuk Meningkatkan Penguasaan Konsep Mahasiswa tentang Gaya dan Gerak. Jurnal Inovasi dan Pembelajaran Fisika. 2017;4(1):27-35.

5. Susrama IBK, Marhaeni A. Pengaruh Penggunaan Metode Resitasi Dan Motivasi Berprestasi Terhadap Kemampuan Menulis Bahasa Inggris Pada Siswa Kelas VIII SMP Negeri 3 Mendoyo. Ganesha University of Education; 2013.

6. Jayanti IBR, Wartono W, Sutopo S. Dampak Program Resitasi Terhadap Perubahan Konseptual Mahasiswa Pada Topik Hukum III Newton. Jurnal Pendidikan: Teori, Penelitian, dan Pengembangan. 2016;1(2):256-264.

7. Ghozali YAF, Sutopo S, Hidayat A. Peningkatan Hasil Belajar dengan Program Resitasi pada Materi Gerak Harmonik Sederhana. Research Report. 2017; .

8. Agustina L, Rusmana IM. Pemanfaatan Ms. Power Point sebagai Alternatif Media Pembelajaran Matematika di Sekolah Dasar. In: PROSIDING SEMINAR DAN DISKUSI PENDIDIKAN DASAR; 2018. .

9. Riduwan MBA. Skala pengukuran variabel-variabel penelitian. Alf Bandung. 2007; 